\title{
Retraction
}

\section{Retracted: Fitz-Hugh-Curtis Syndrome in a Male Patient: A Case Report and Literature Review}

\author{
Case Reports in Surgery \\ Received 5 October 2015; Accepted 5 October 2015 \\ Copyright (C) 2015 Case Reports in Surgery. This is an open access article distributed under the Creative Commons Attribution \\ License, which permits unrestricted use, distribution, and reproduction in any medium, provided the original work is properly \\ cited.
}

The paper titled "Fitz-Hugh-Curtis Syndrome in a Male Patient: A Case Report and Literature Review" [1] has been retracted as it was found to have been published before by the same authors in Journal of Surgical Case Reports (J Surg Case Rep. 2012 Mar; 2012(3): 12).

\section{References}

[1] S. Saurabh, E. Unger, and C. Pavlides, "Fitz-hugh-curtis syndrome in a male patient: a case report and literature review," Case Reports in Surgery, vol. 2012, Article ID 457272, 3 pages, 2012. 